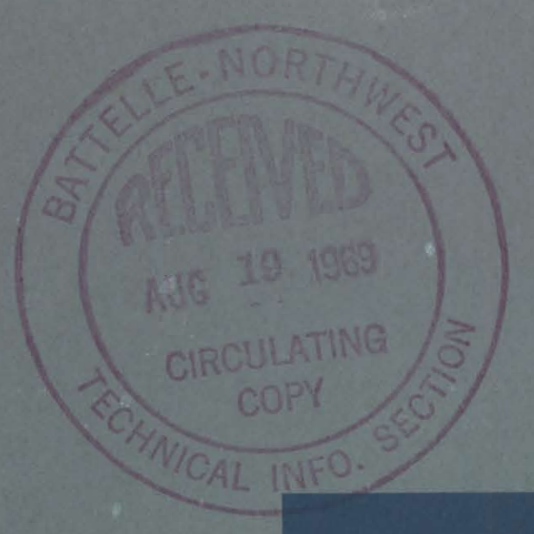

BNWL-1112 UC-25

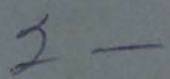

\title{
YIELD SURFACE
}

OF A URANIUM-7.5 wt\%

Nb-2.5 wt\% Zr ALLOY (MULBERRY)

August 1969

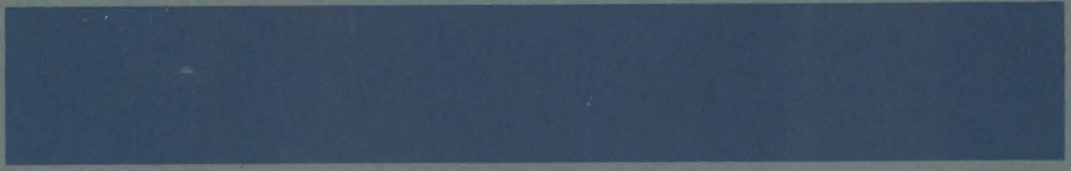

\section{AEC RESEARCH \& DEVELOPMENT REPORT}

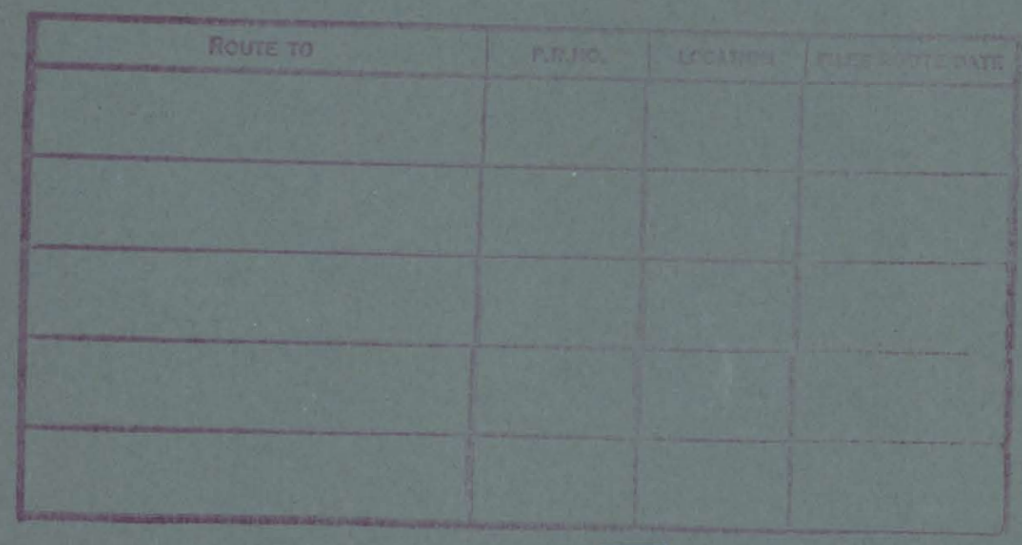




\section{LEGAL NOTICE}

This report was prepared as an account of Government sponsored work. Neither the United States, nor the Commission, nor any person acting on behalf of the Commission:

A. Makes any warranty or representation, expressed or implied, with respect to the accuracy, completeness, or usefulness of the information contained in this report, or that the use of any information, apparatus, method, or process disclosed in this report may not infringe privately owned rights; or

B. Assumes any liabilities with respect to the use of, or for damages resulting from the use of any information, apparatus, method, or process disclosed in this report.

As used in the above, "person acting on behalf of the Commission" includes any employee or contractor of the Commission, or employee of such contractor, to the extent that such employee or contractor of the Commission, or employee of such contractor prepares, disseminates, or provides access to, any information pursuant to his employment or contract with the Commission, or his employment with such contractor.

\section{PACIFIC NORTHWEST LABORATORY}

RICHLAND, WASHINGTON

operated by

BATTELLE MEMORIAL INSTITUTE

for the

UNITED STATES ATOMIC ENERGY COMMISSION UNDER CONTRACT AT(45-1)-1830 


\section{BNWL -1112}

UC-25, Metals, Ceramics, and Materiais

YIELD SURFACE OF A URANIUM-7.5 wt\% Nb-2.5 wt\% Zr ALLOY (MULBERR:;

$$
\text { D. D. Hays }
$$

Metallurgy Development Department Chemistry and Metallurgy Division

August 1969 
Printed in the United States of America Available from

Clearinghouse for Federal Scientific and Technical Information National Bureau of Standards, U.S. Department of Commerce Springfield, Virginia 22151

Price: Printed Copy $\$ 3.00$; Microfiche $\$ 0.65$ 
YIELD SURFACE OF A URANIUM-7.5 wt\% Nb-2.5 wt\% ALLOY (MULBERRY) D. D. Hays

\section{ABSTRACT}

The biaxial yield surface of a gamma stabilized uranium-7.5 wt\% $\mathrm{Nb}-2.5 \mathrm{wt} \% \mathrm{Zr}$ alloy (Mulberry) was determined. The yield surface is best described by the maximum strain (Von Mises) theory of yielding. 


\section{TABLE OF CONTENTS}

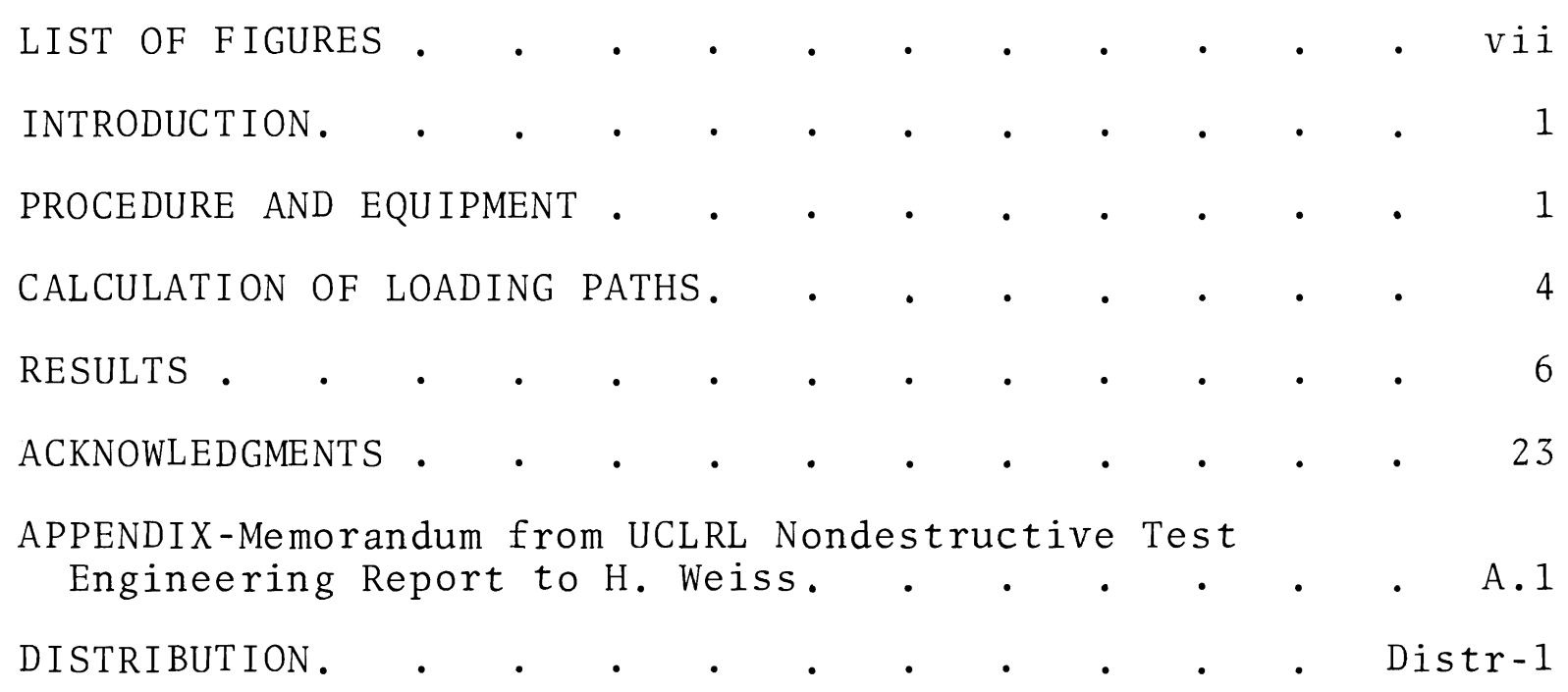




\section{LIST OF FIGURES}

1 Biaxial Specimen 2

2 Stress Paths for Testing of Mulberry Samples 3

3 Sample 004 Axial Stress Versus Strain 8

4 Sample 002 Axial Stress Versus Strain 9

5 Sample 001 Axial Stress Versus Strain 10

6 Sample 001 Hoop Stress Versus Strain 11

7 Sample 001 Axial Strain Versus Hoop Strain 12

8 Sample 006 Axial Stress Versus Strain 13

9 Sample 006 Hoop Stress Versus Strain 14

10 Sample 006 Axial Strain Versus Hoop Strain 15

11 Sample 003 Axial Stress Versus Strain 16

12 Sample 003 Hoop Stress Versus Strain 17

13 Sample 003 Axial Strain Versus Hoop Strain 18

14 Sample 007 Axial Stress Versus Strain 19

15 Sample 007 Hoop Stress Versus Strain 20

16 Sample 005 Axial Stress Versus Strain 21

17 Sample 005 Hoop Stress Versus Strain 22

18 Sample 003-2 Hoop Stress Versus Strain 24

$190.05 \%$ Yield Surface for Mulberry Alloys 25 
YIELD SURFACE OF A URANIUM-7.5 wt\% Nb-2.5 wt\% ALLOY (MULBERRY) D. D. Hays

\section{INTRODUCTION}

The purpose of this investigation was to experimentally determine the yield surface of a gamma stabilized uranium$7.5 \mathrm{wt} \% \mathrm{Nb}-2.5 \mathrm{wt} \% \mathrm{Zr}$ a11oy (hereafter referred to as Mulberry) under biaxial stress conditions. The work was done for the Sandia Corporation under the direction of UCLRL who provided the test specimens, grips, and fixtures.

\section{PROCEDURE AND EQUIPMENT}

The test specimens (Figure 1) were made by the Y-12 Division of the Oak Ridge National Laboratory according to specifications written by UCLRL.

Basically, the test consisted of subjecting the specimens to internal pressurization as well as compressive or tensile loads until yielding occurs. This type of testing produces axial and hoop stresses which can be varied as desired by using different combinations of pressure and load.

The original testing program called for 15 samples but, due to fabrication difficulties, only 7 were actually made. Two of these samples were found to be unsuitable for biaxial testing because of cracks in the gage length (see Appendix for complete UCLRL inspection report). Based on the inspection of these samples and discussions with Sandia, the stress paths shown in Figure 2 were chosen for investigation. Single specimens were tested along stress paths, i.e. hoop stress/axial stress ratios of $+1,-2$, and $-1 / 2$, and 2 specimens were tested along the -1 stress path. The two samples unsuitable for biaxial testing were tested in uniaxial tension and compression to establish boundary conditions for the biaxial tests. 
BNWL - 1112

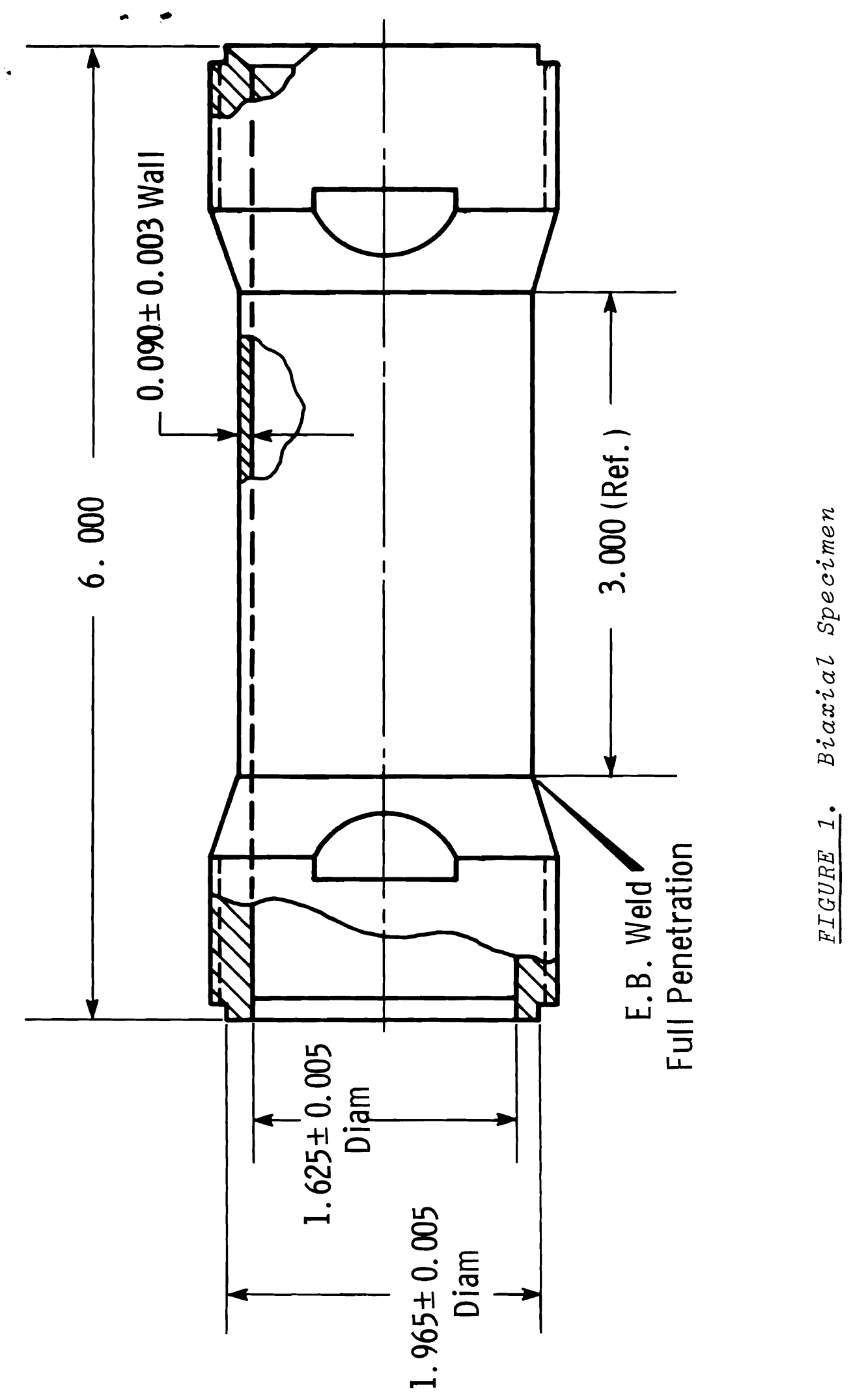




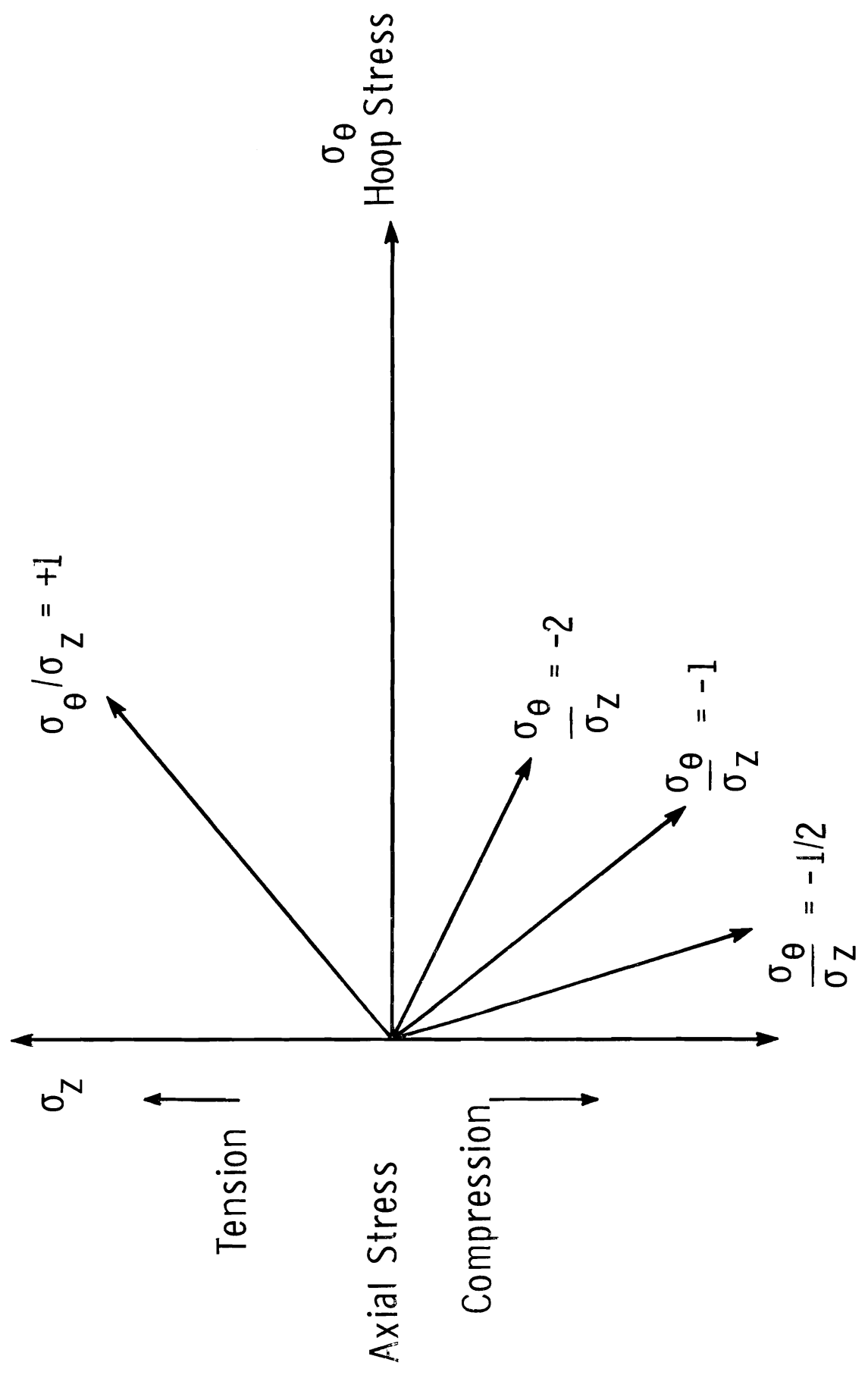


Axial loading was done with a Baldwin Universal Testing Machine. The loading precision was $\pm 251 \mathrm{~b}$ (about \pm 50 psi axial stress for these samples). An air-driven hydraulic pump was used for pressurization of the samples. The pressure was measured with a calibrated Stathem 10,000 psi pressure transducer. The internal pressure could be read to $\pm 2.5 \mathrm{psi}$ (about \pm 20 psi hoop stress).

Strain was recorded on four $90^{\circ}$ rosette strain gages cemented at $90^{\circ}$ intervals around the center of the specimen gage length. The strain was read to the nearest $5 \mu$ in. on a Baldwin SR-4 box connected to a Baldwin 20-channel switching and balancing unit. Since axial bending was known to be a problem when testing this type of sample, an arbitrary standard requiring all axial gages to read within $\pm 10 \%$ of the average strain was adopted.

\section{CALCULATION OF LOADING PATHS}

The following is a key to the nomenclature used in this section:

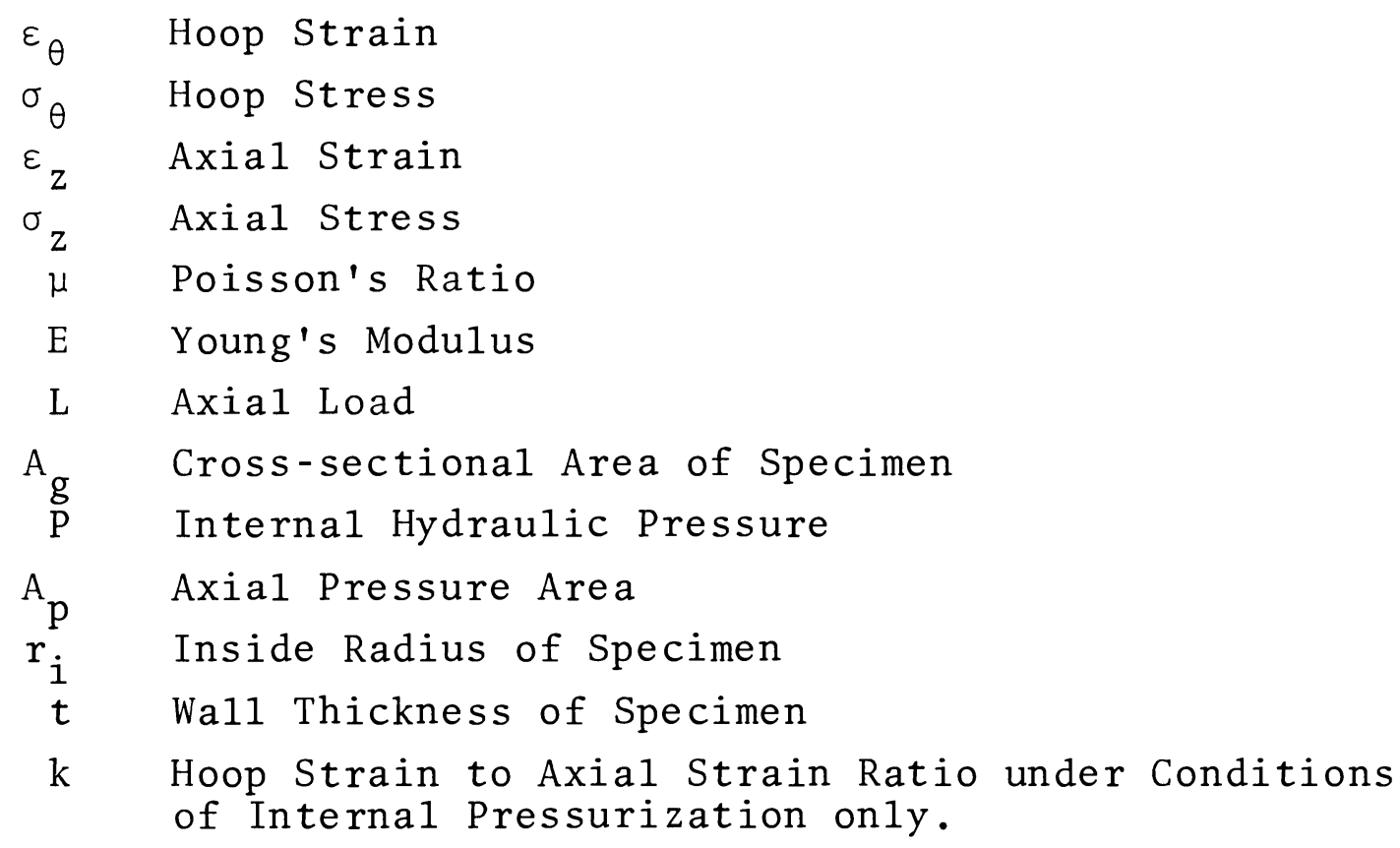


The loading paths were calculated according to a procedure described by Green.*

For this type of testing, the elastic stress-strain relationships can be expressed by:

$$
\begin{aligned}
& \varepsilon_{\theta}=\frac{1}{\bar{E}}\left(\sigma_{\theta}-\mu \sigma_{z}\right) \\
& \varepsilon_{z}=\frac{1}{\bar{E}}\left(\sigma_{z}-\mu \sigma_{\theta}\right)
\end{aligned}
$$

The axial stress is given by:

$$
\sigma_{z}=\frac{L}{A_{g}}+P \frac{A}{A_{g}}
$$

The hoop stress for a thin wall cylinder is given by:

$$
\sigma_{\theta}=\frac{\operatorname{Pr}_{i}}{t}
$$

Dividing Equation (1) by Equation (2)

$$
\frac{\varepsilon_{\theta}}{\varepsilon_{z}}=\frac{\sigma_{\theta}-\mu \sigma_{z}}{\sigma_{z}-\mu \sigma_{\theta}}=\mathrm{k}
$$

Substituting into Equation (5) the expression for $\sigma_{\theta}$ from Equation (4), and $\sigma_{z}$ from Equation (3) gives:

$$
A_{p}+\frac{L}{P}=A_{g} \frac{r_{i}}{t}\left(\frac{1+k \mu}{k+\mu}\right)
$$

Before a sample could be biaxially tested, it was necessary to do two pretests. These pretests consisted of measuring $\varepsilon_{z}$ and $\varepsilon_{\theta}$ under (1) axial loading only, and (2) internal pressurization only. In the axial loading pretest, the sample was elastically loaded in small increments in either axial tension or compression depending on the biaxial stress path chosen for that sample. Poisson's ratio was calculated from the measured hoop and axial strains.

* E. A. Green. "The Yield Surface of Uranium + $0.75 \%$ Titanium," UCID-15362, July 30, 1968. 
From the "pressurization only" pretest, " $k$ " in Equation was calculated. As discussed by Green, * it was necessary to experimentally determine $A_{p}$. $A_{p}$ was calculated from Equation (6), since $L=0$.

The axial load and internal pressure were determined by first calculating the pressure (P) required for a given hoop stress from Equation (4). The value of $P$ is then substituted into Equation (3), which is solved for the corresponding axial load, L, to give the desired hoop stress-to-axial stress ratio.

Hoop Stress increments of 2500 psi were selected for use in the testing of Mulberry. After the loading paths had been calculated, the test procedure was to apply the axial load first, then the pressure. After the gages were read, the axial load and pressure were increased to the next value and the gages read again. Because creep was found to occur at relatively low loads, the time between data points was kept constant at about $3 \mathrm{~min}$. The sample was loaded until it was obvious from the strain increments that yielding had occurred. The samples were then unloaded. Unloading data were obtained when possible to detect any modulus change that might occur during testing. Axial stress versus strain and hoop stress versus strain curves were plotted for each stress path. Since deviation from linearity was found to occur at very low loads, an arbitrary yield strength of $0.05 \%$ offset was used to define the yield surface.

\section{RESULTS}

A summary of all the testing results (Table 1) shows the stress path and $0.05 \%$ yield strength for each sample. The stress-strain curves for these samples are shown in Figures 3 through 18. Examination of the unloading data for these samples shows a moderate amount of mechanical hysteresis. Although

* E. A. Green. "The Yield Surface of Uranium + 0.75\% Titanium," UCID-15362, p. 2, July 1968. 
TABLE 1. Biaxial yield Strengths of Mulberry Alzoy as a Function of Stress Path

\begin{tabular}{|c|c|c|c|}
\hline \multirow{2}{*}{ Sample Number } & \multirow{2}{*}{$\begin{array}{c}\text { Stress Path, } \\
\sigma_{\theta} / \sigma_{z} \\
\end{array}$} & \multicolumn{2}{|c|}{$\frac{0.05 \% \text { Yield }}{\text { Strondth }}$} \\
\hline & & Axial & Hoop \\
\hline 004 & Tension & 61,000 & -- \\
\hline 001 & +1 & 70,500 & 67,500 \\
\hline 007 & -2 & 28,750 & 47,750 \\
\hline 003 & -1 & 41,250 & 40,000 \\
\hline 006 & -1 & 50,000 & 44,750 \\
\hline 005 & $-1 / 2$ & 59,500 & 30,000 \\
\hline 002 & Compression & 74,500 & -- \\
\hline $003-2$ & $\infty$ (Hoop) & 50,750 & -- \\
\hline
\end{tabular}

this condition complicates the determination of an unloading modulus, no large modulus changes were apparent as the result of testing.

Figures 3 and 4 show, respectively, the uniaxial tensile and compression curves for samples 004 and 002 . These samples contained cracks in the gage length and were not suitable for biaxial testing. The large difference between the compressive and tensile yield strengths is probably caused by the cracks. Based on other uniaxial tensile data for this alloy, the compressive yield strength was used in plotting he yield surface.*

Examination of the data for stress paths +1 and -1 (Figures 5 through 13) shows evidence of some anisotropy in tisese samples. Even though the axial and hoop stresses were equal along these stress paths, the samples yielded in the hoop direction first. Yielding in the hoop direction is especially apparent in Figures 7 and 10 , where axial strain

$\because$ E. A. Green. Personal Communication. 
BNWL- 1112

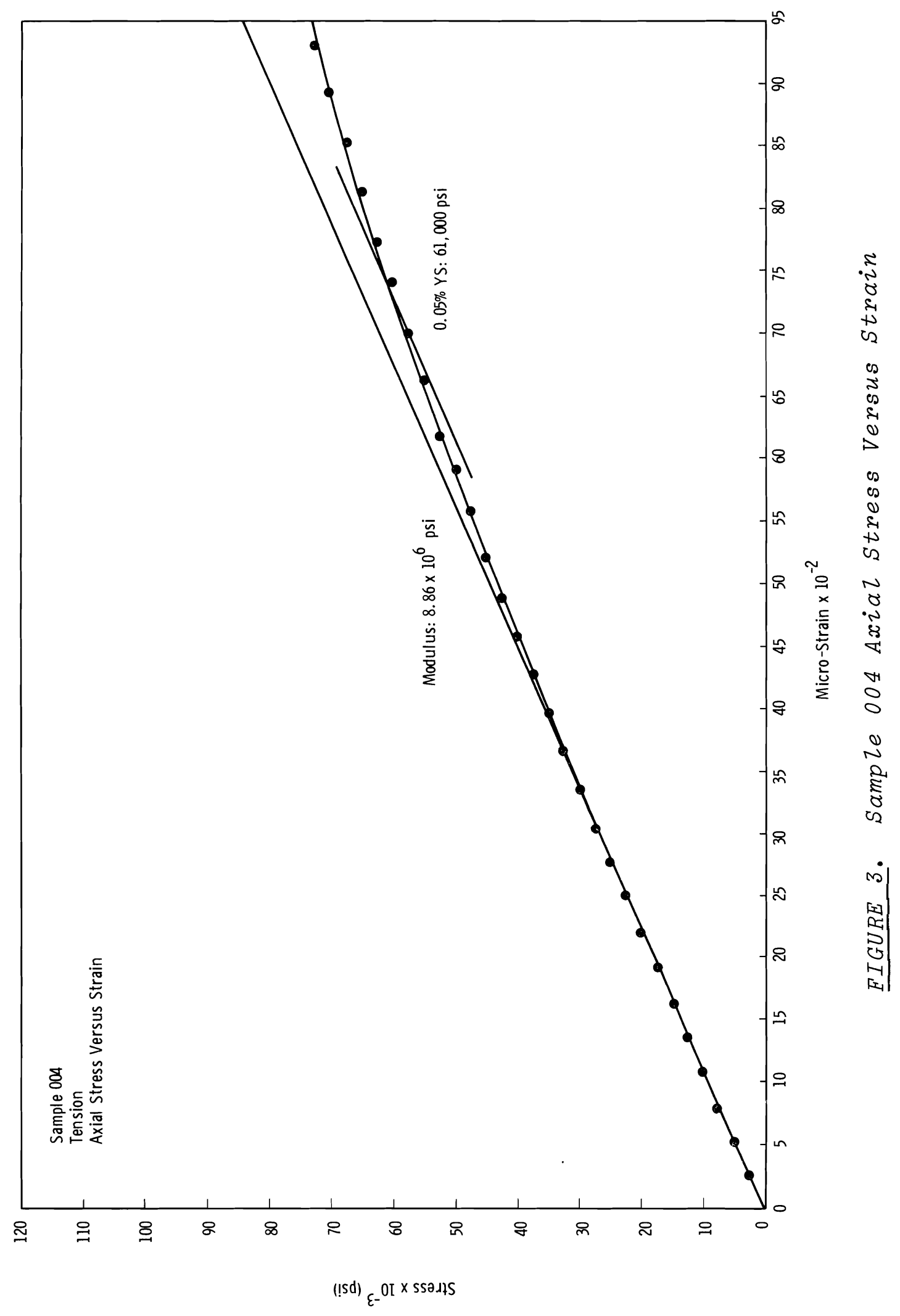


BNWL-1112

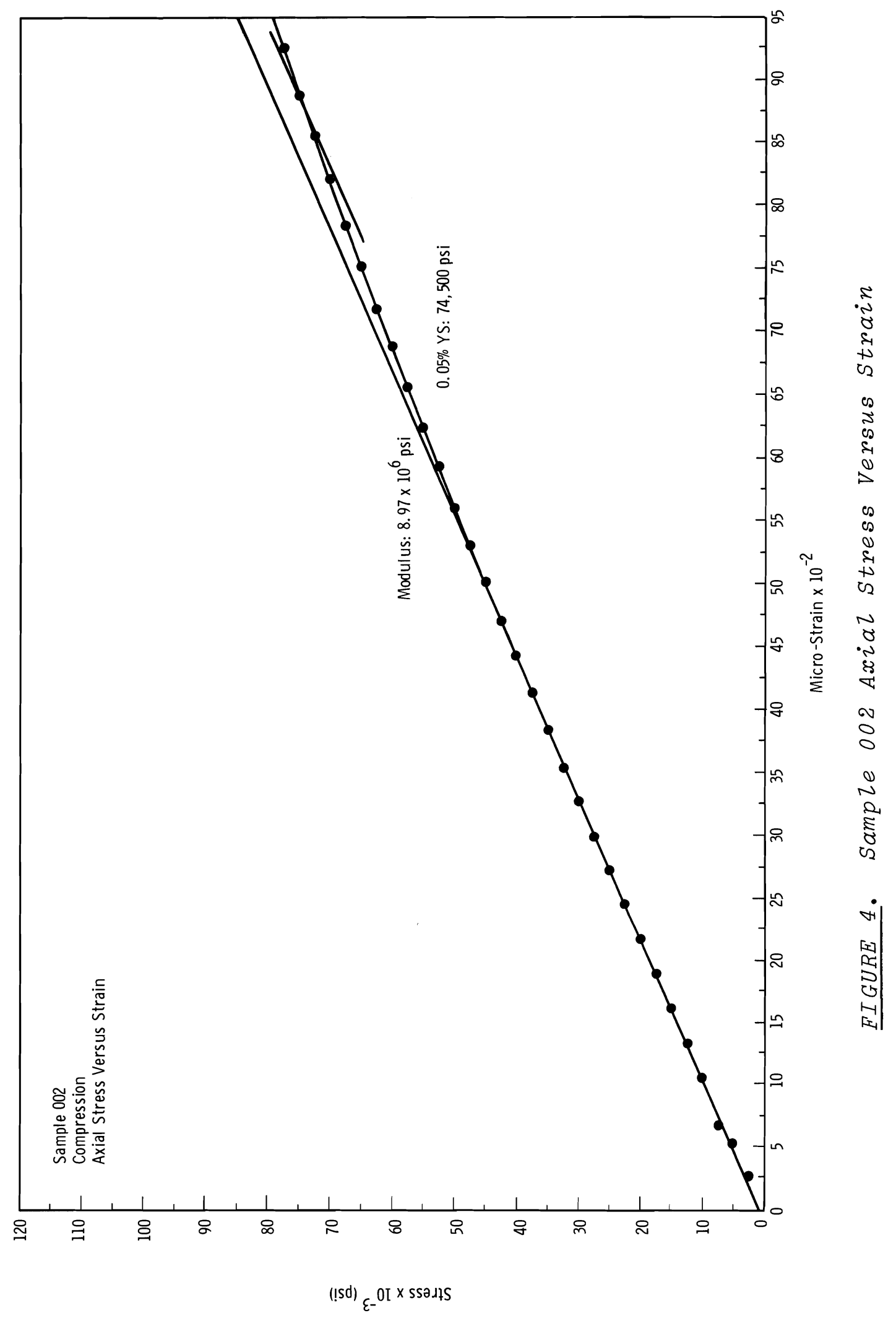


BNWL - 1112

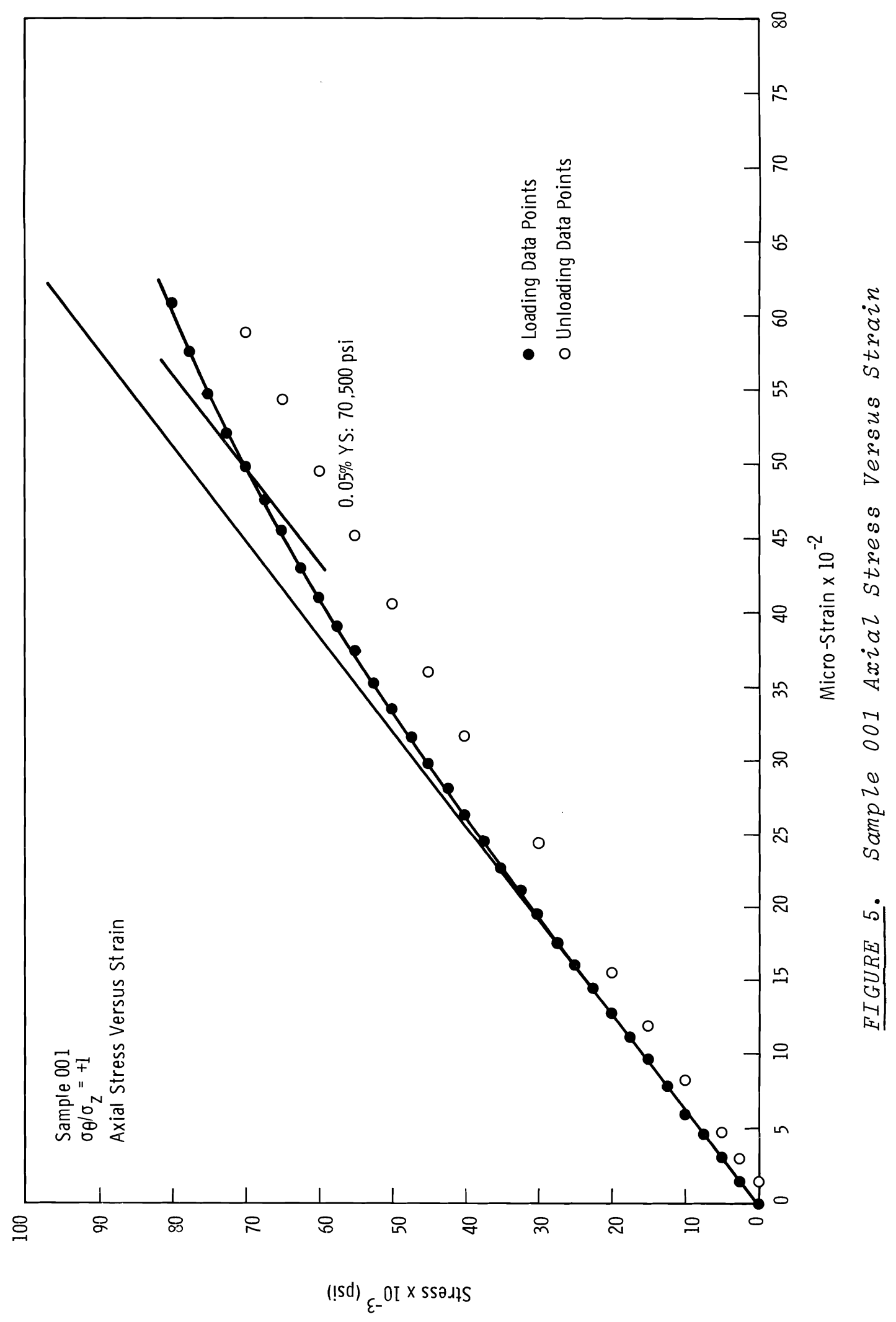


BNWL -1112

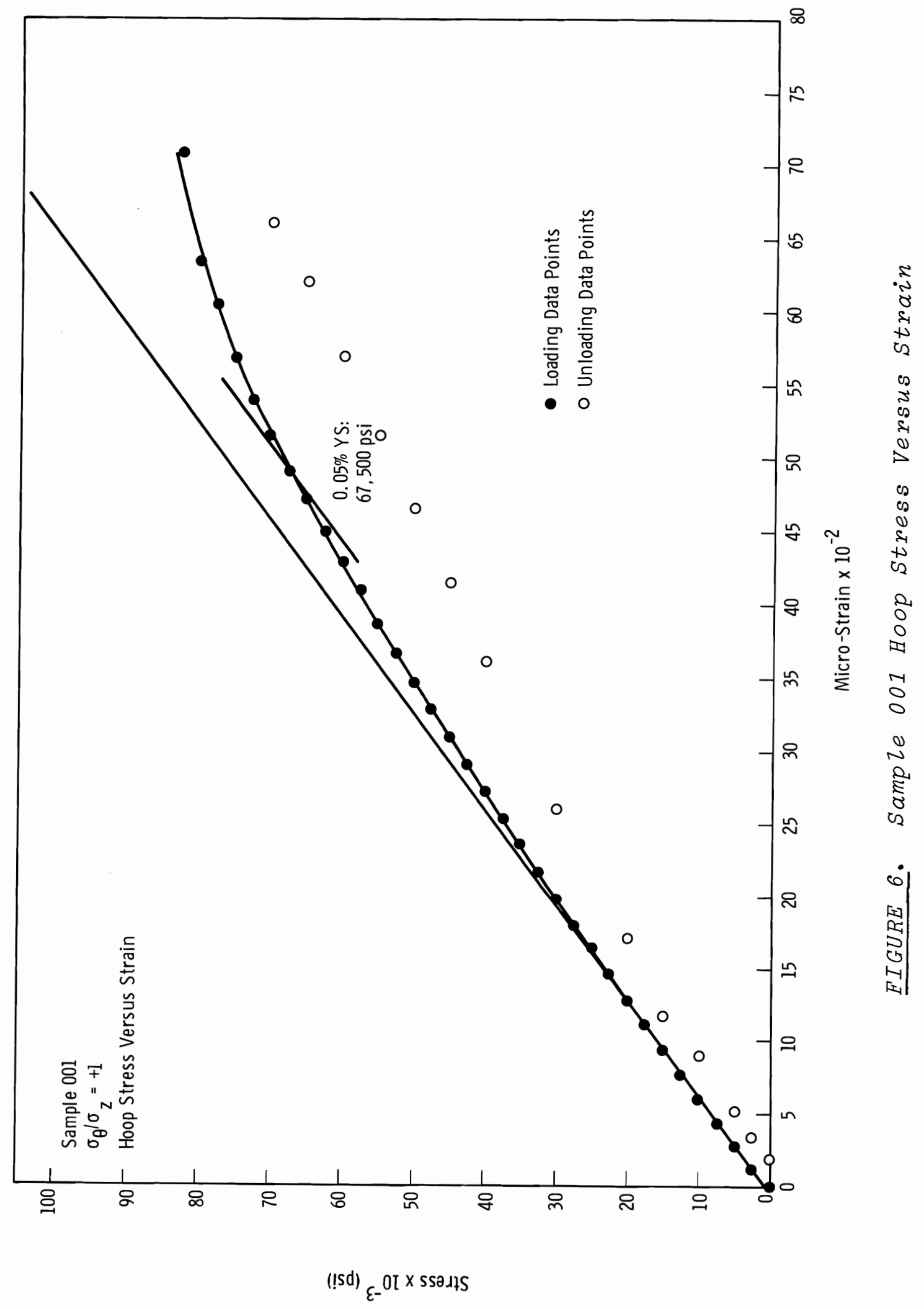




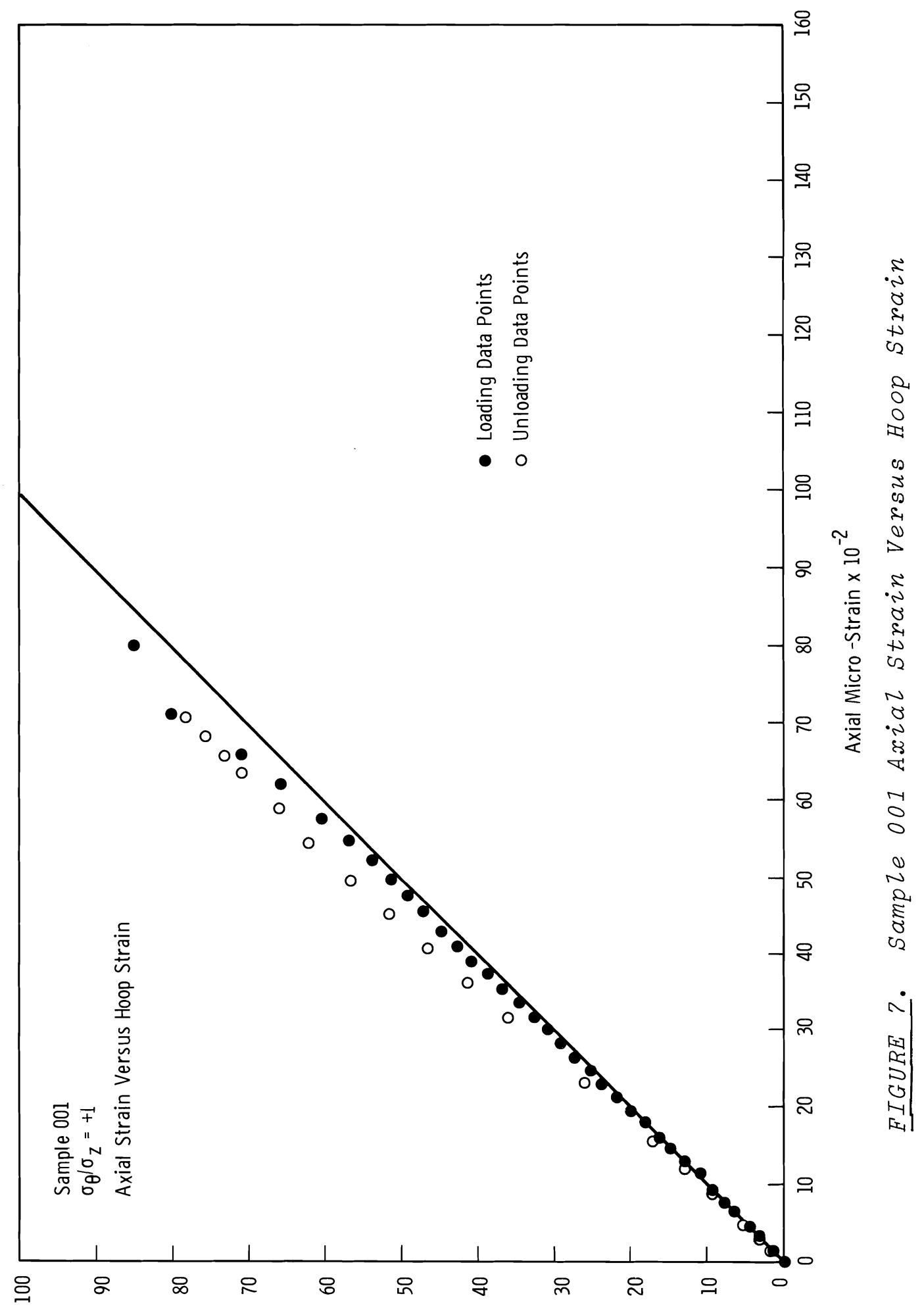

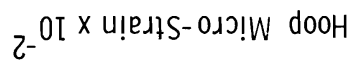


BNWL - 1112

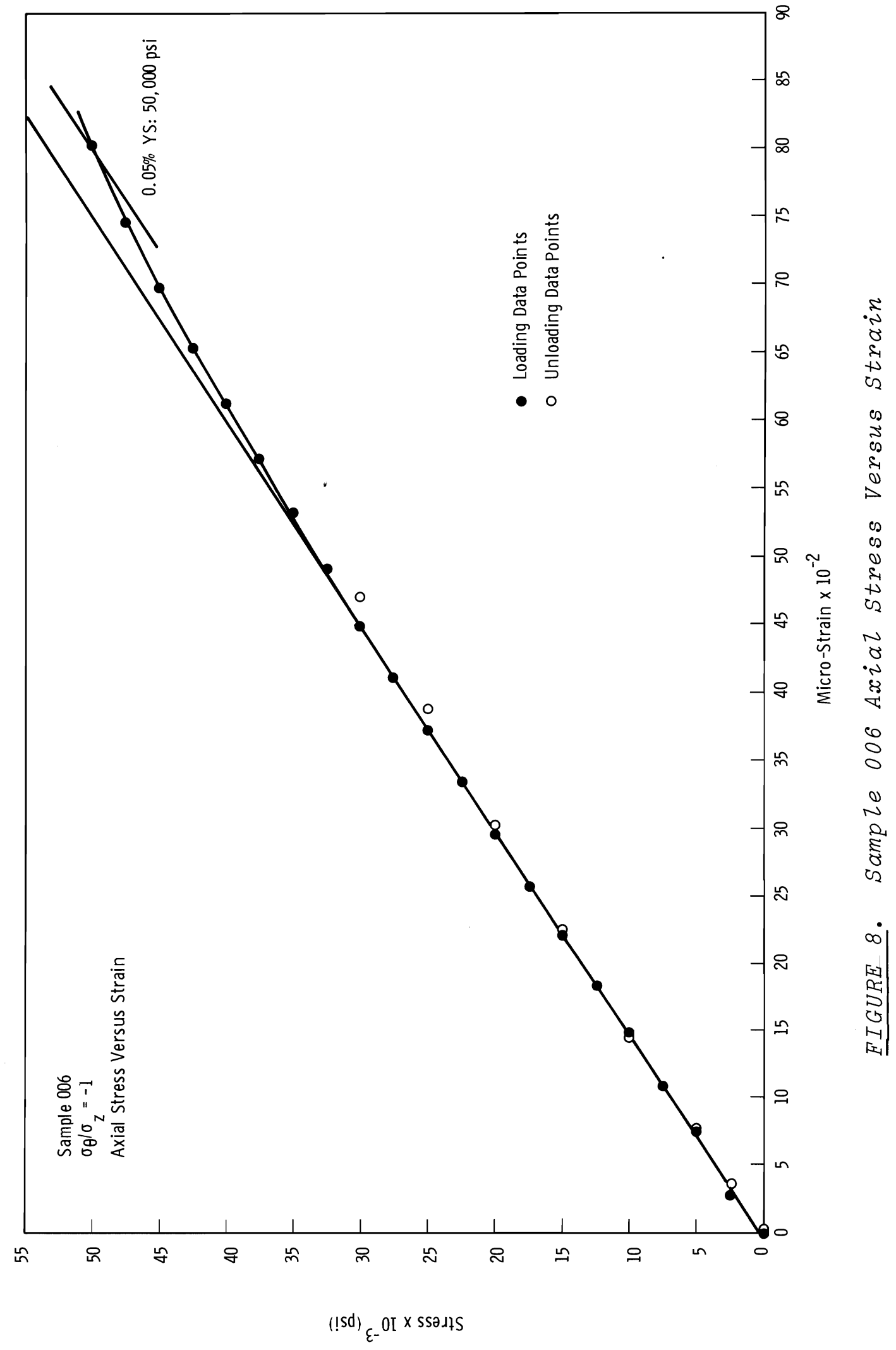


BNWL - 1112

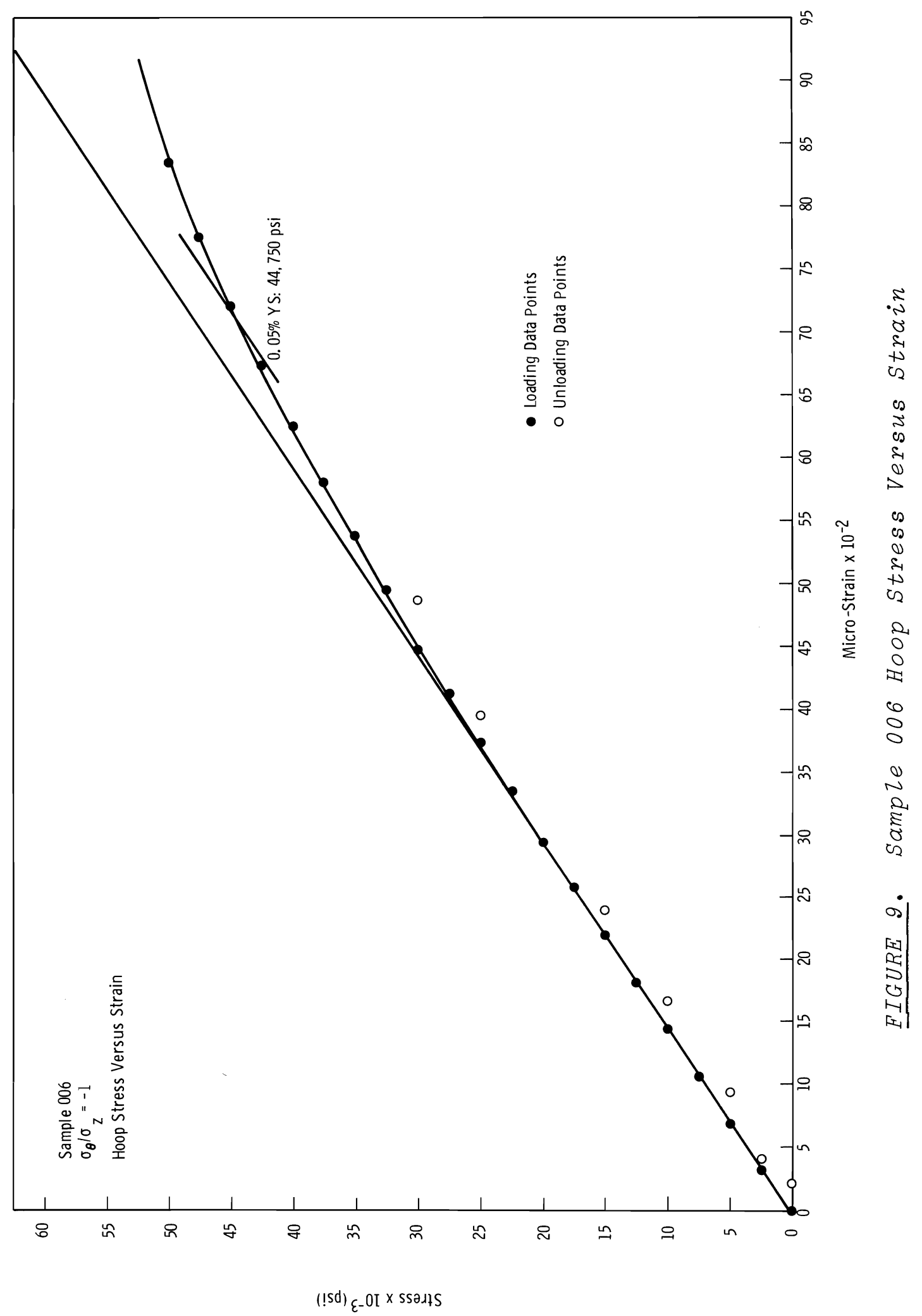


BNWL - 1112

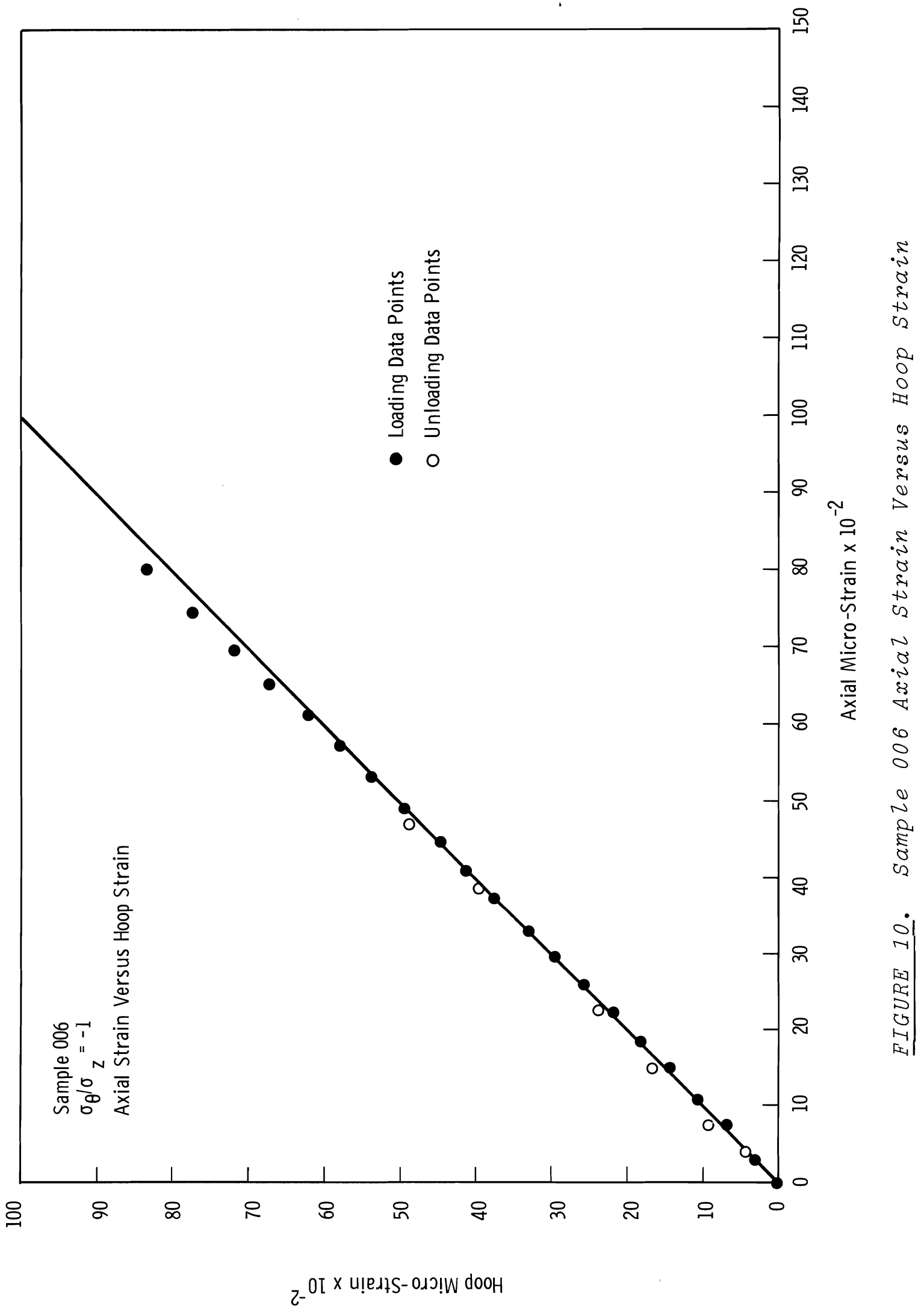


BNWL -1112

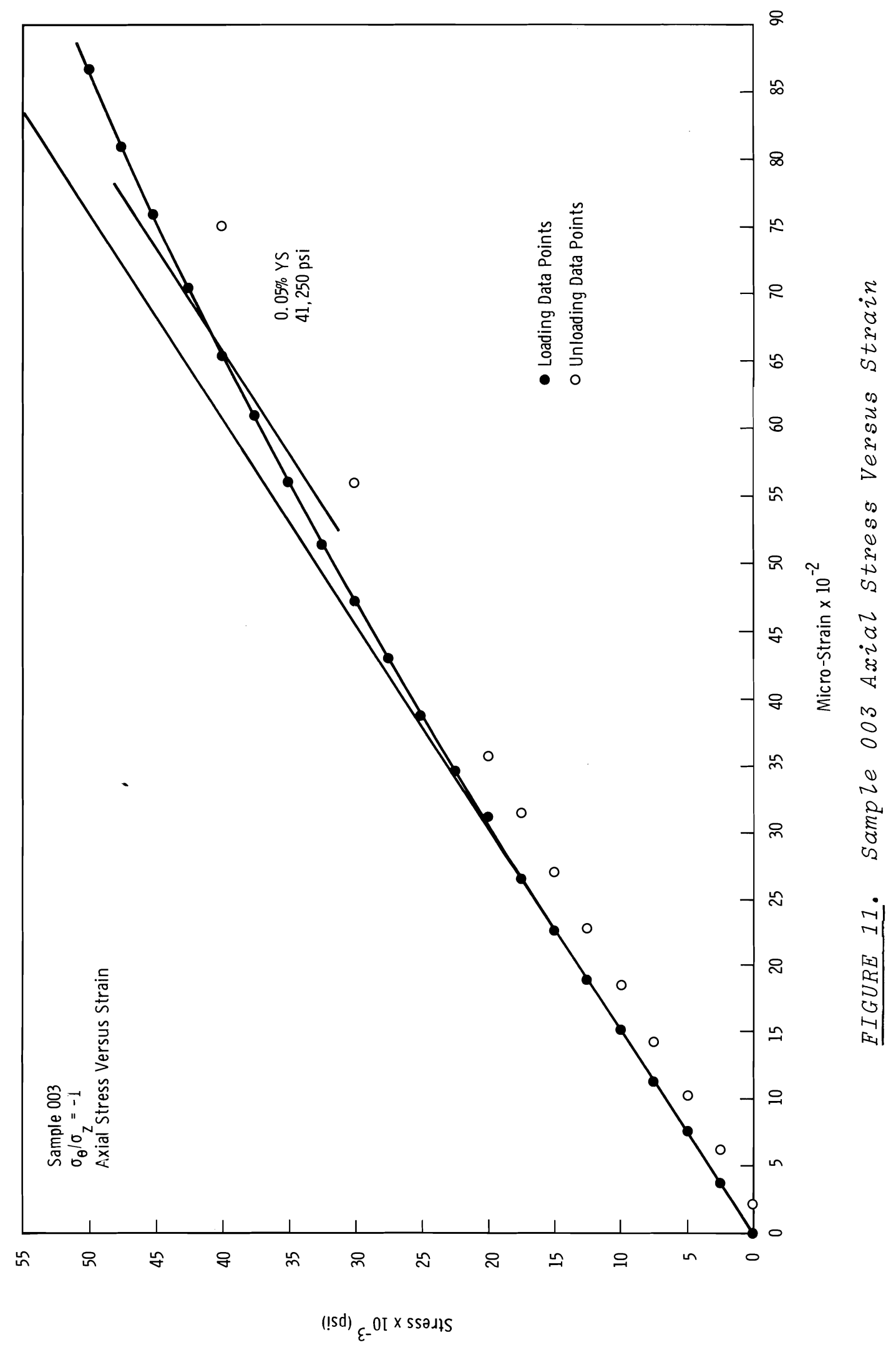


BNWL - 1112

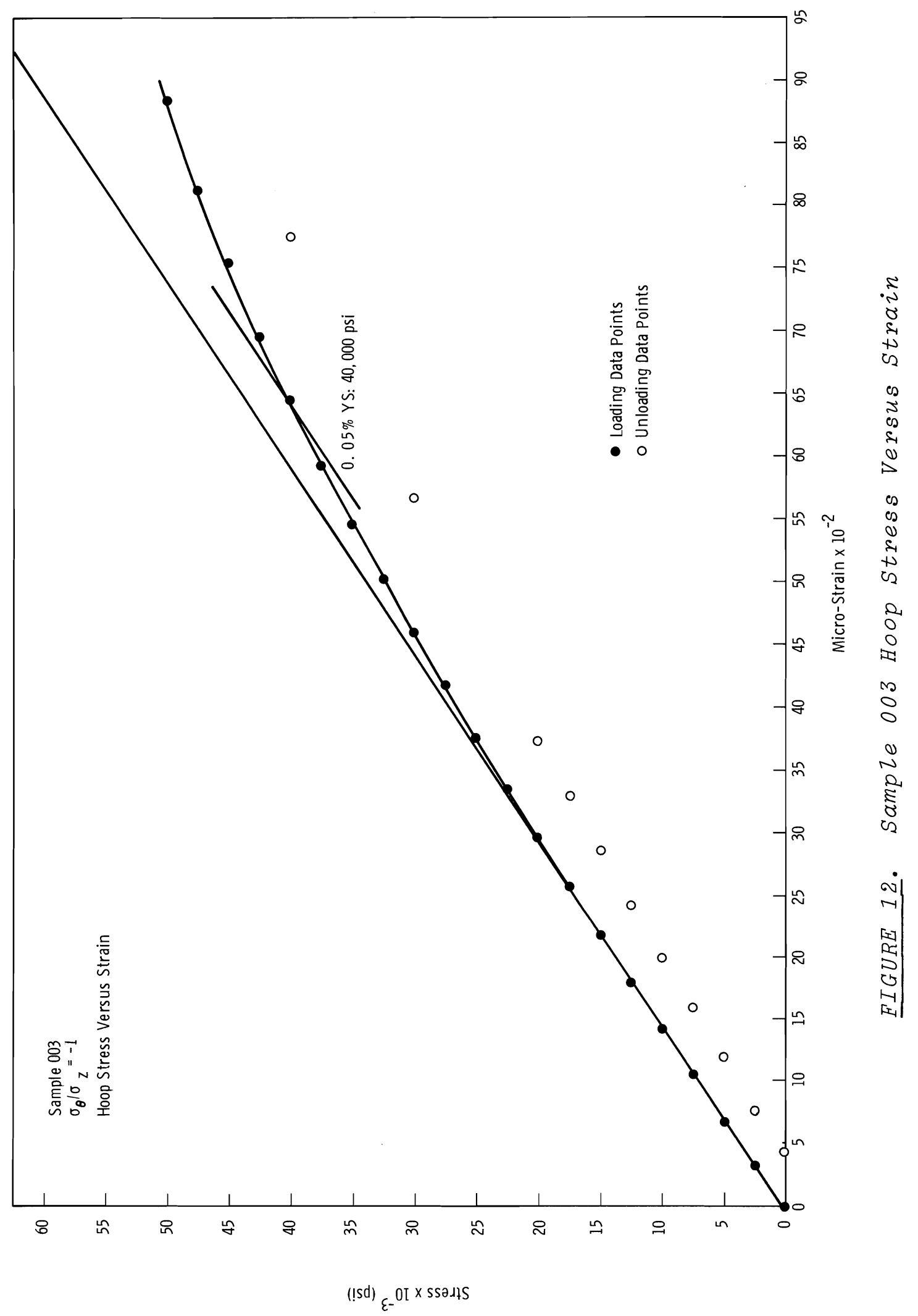




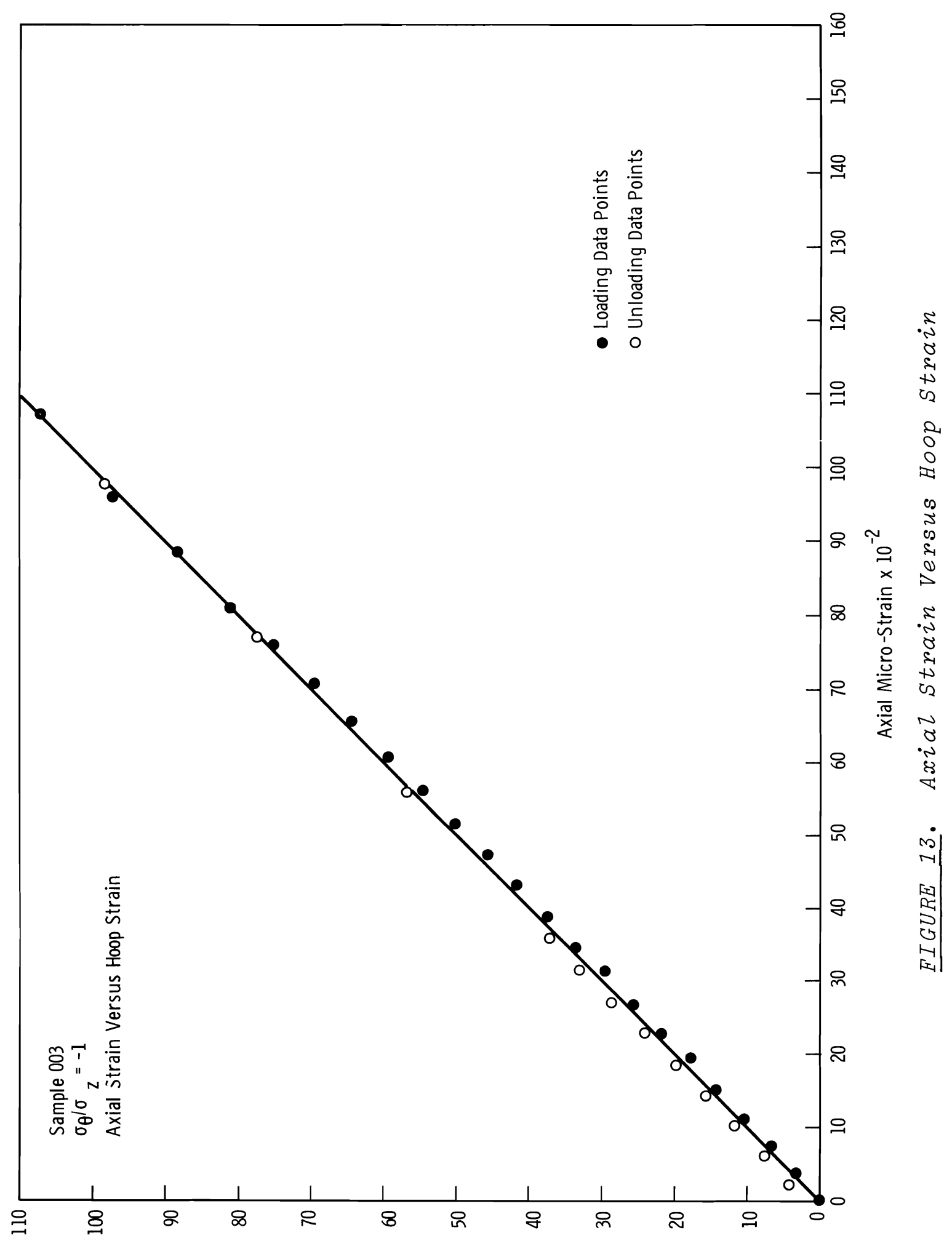

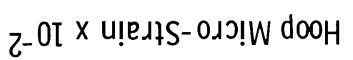




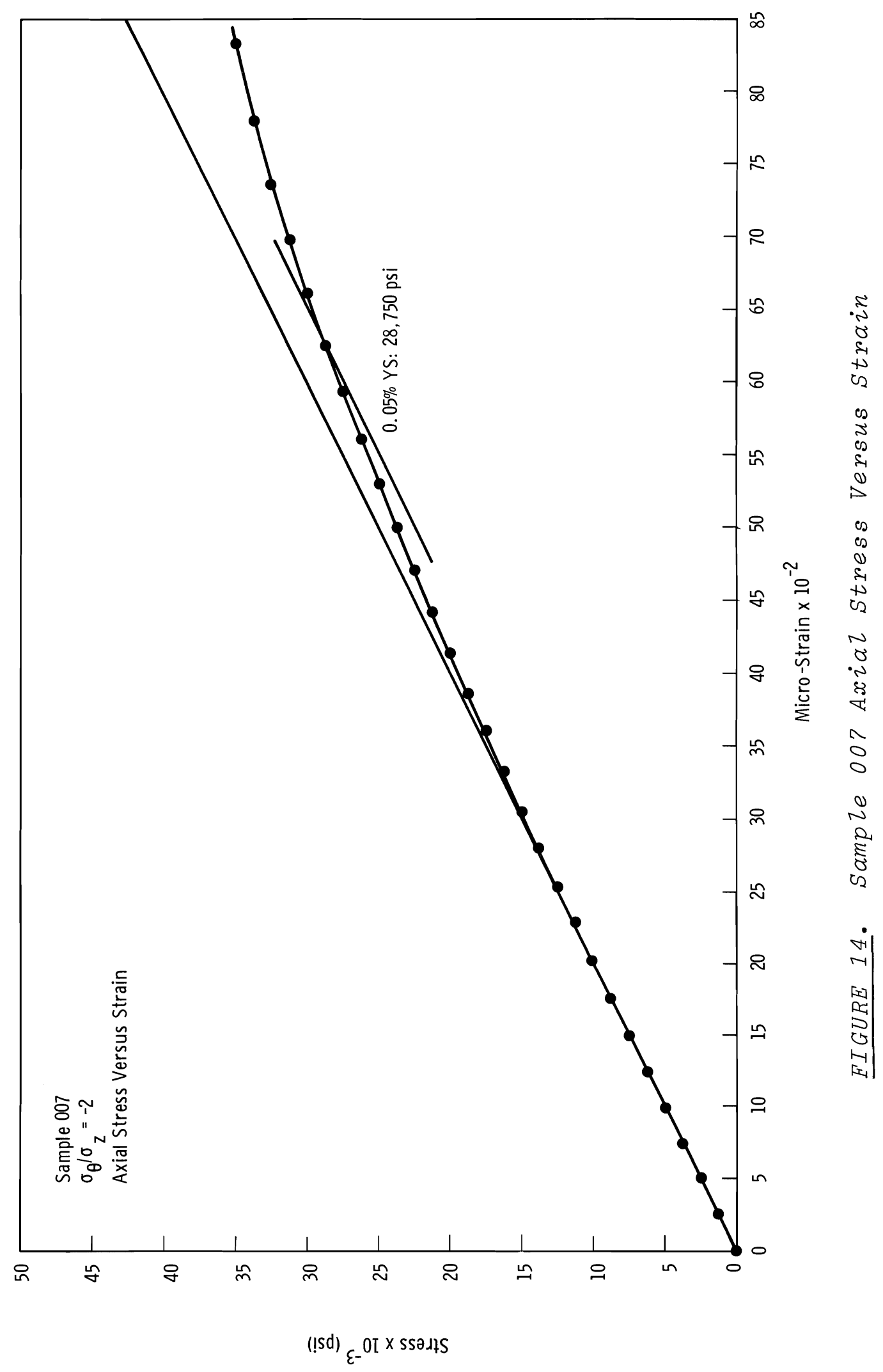


BNWL -1112

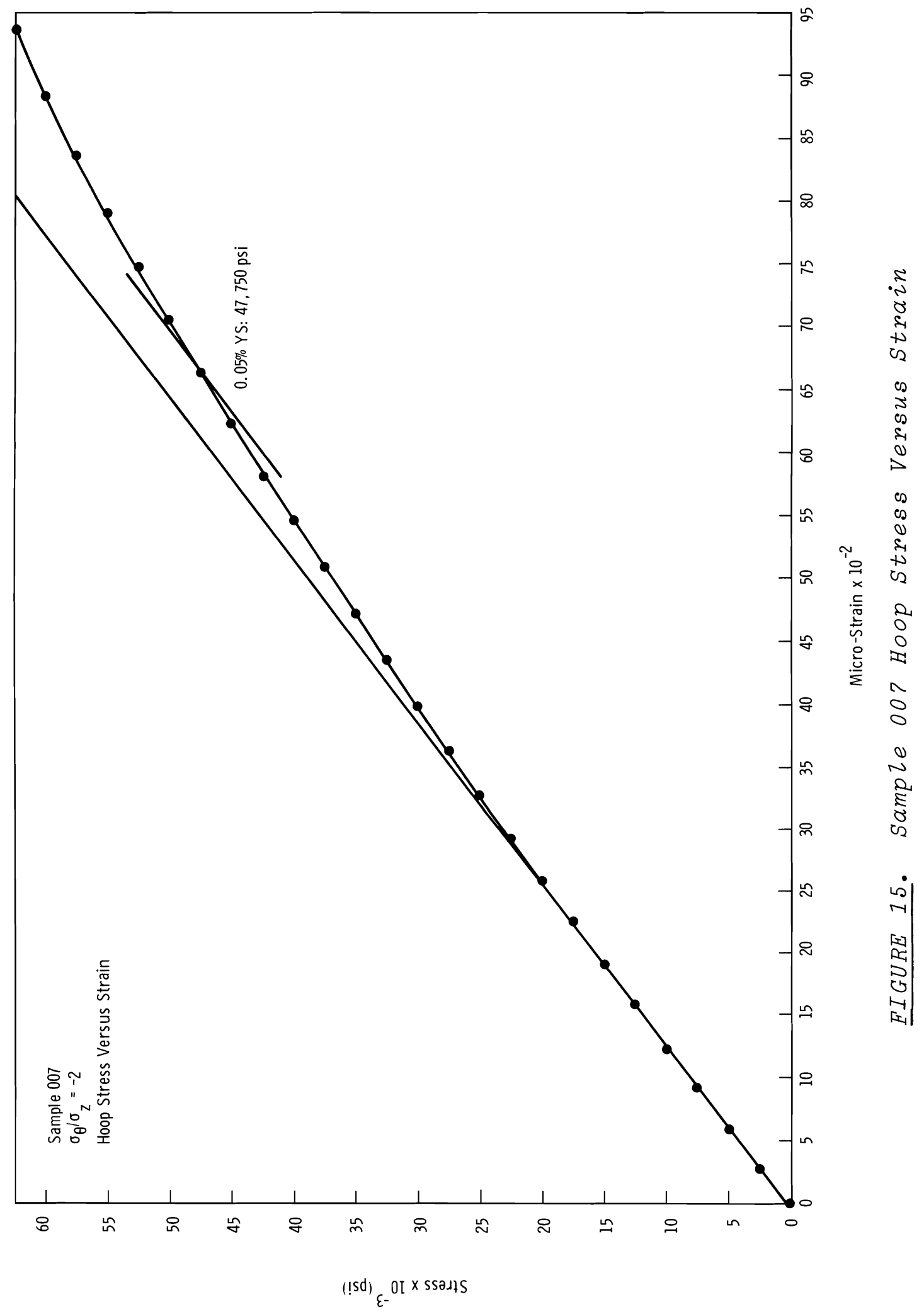


BNWL - 1112

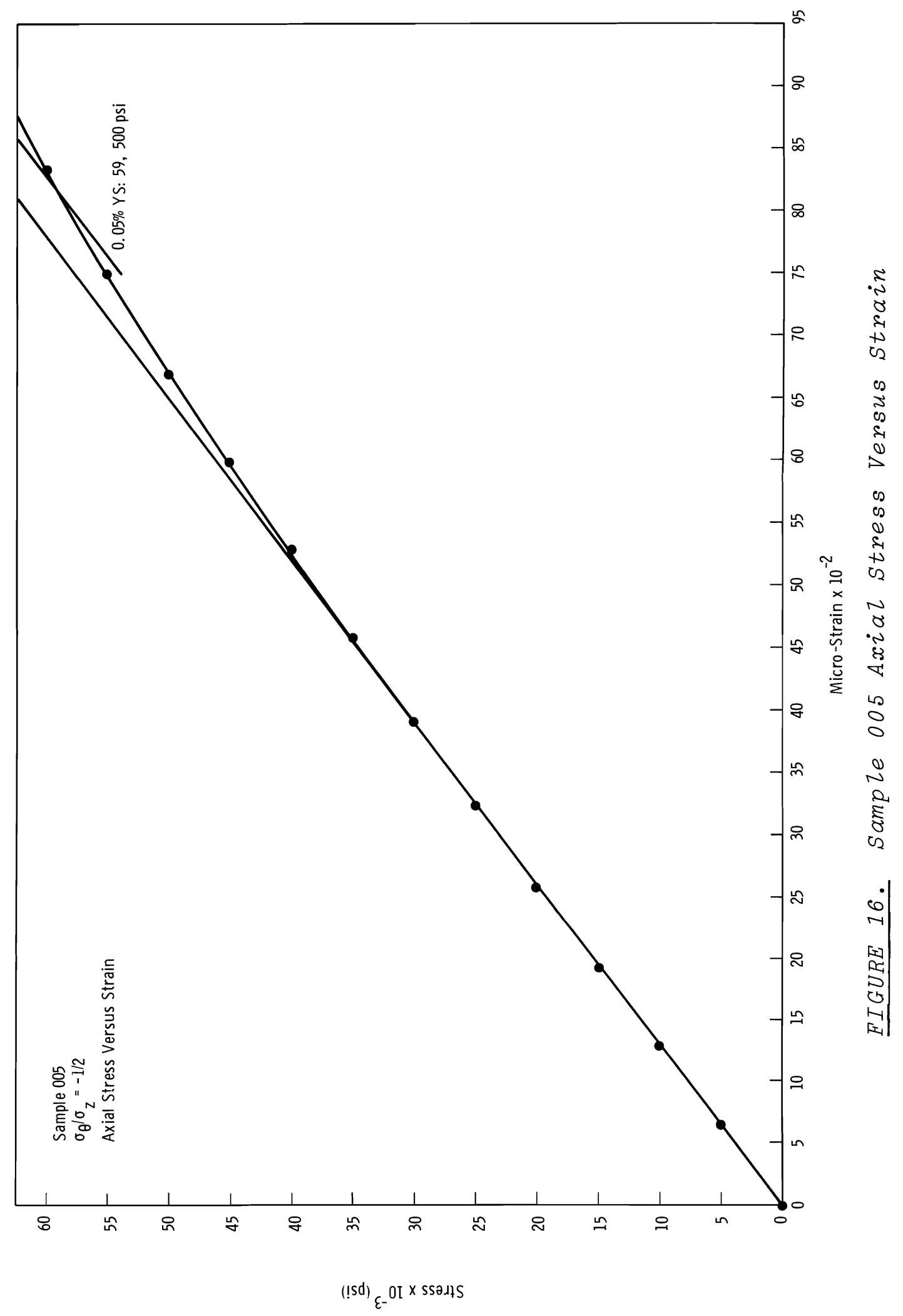


BNWL- 1112

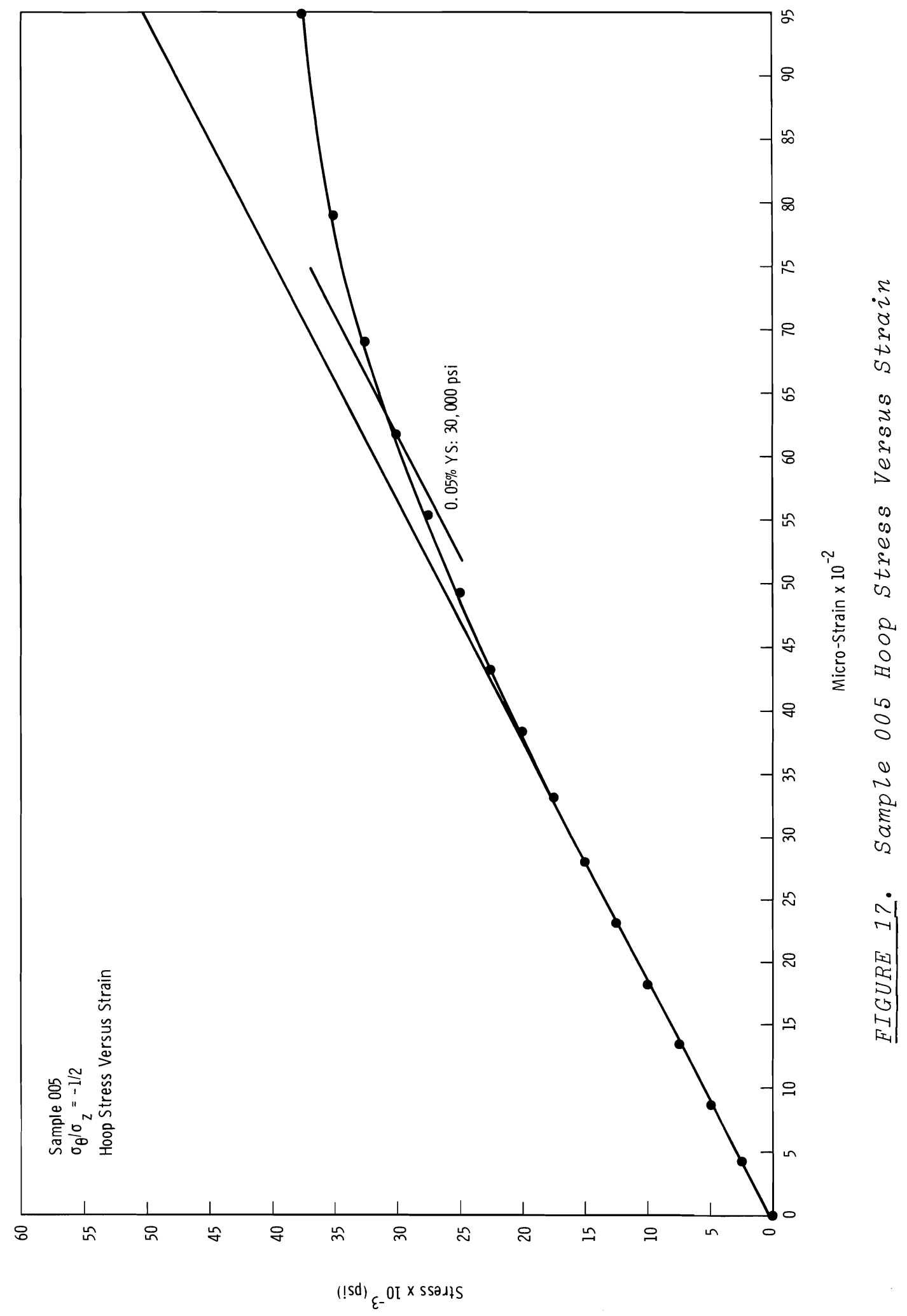


is plotted versus hoop strain for samples 001 and 006 . A reference line at $45^{\circ}$ has been drawn on each of these graphs. The strains obtained during testing along a +1 or -1 stress path should fall along the reference line. The data points fall very close to the reference line at low stress, but at high stress, the samples yield in the hoop direction first. Sample 003 shows a lesser degree of anisotropy (Figure 13).

Sample 003 was retested under conditions of hoop stress only, after testing to yield along the -1 stress path. The sample yielded in the hoop direction at 50,750 psi (Figure 18), which is considerably lower than one would expect based on the degree of anisotropy observed in the other tests with these samples. There appears to be no explanation for the extremely low yield strength shown by this sample.

Figure 19 shows the $0.05 \%$ yield surface of the Mulberry alloy as plotted from the data in Table 1. A1so, shown in the figure are the surfaces predicted by the maximum stress and maximum strain (Von Mises) theory of yielding. With the exception of the $\sigma_{\theta} / \sigma_{z}=\infty$ path (hoop stress only), the yielding data for this alloy gives reasonable fit to the Von Mises theory in the fourth quadrant. It is not possible to define the yield surface in the first quadrant with only the one point along the +1 stress path.

\section{ACKNOWLEDGMENTS}

The author would like to thank E. A. Green, Lawrence Radiation Laboratory, for valuable discussions and the loan of several items of test equipment. 
BNWL -1112

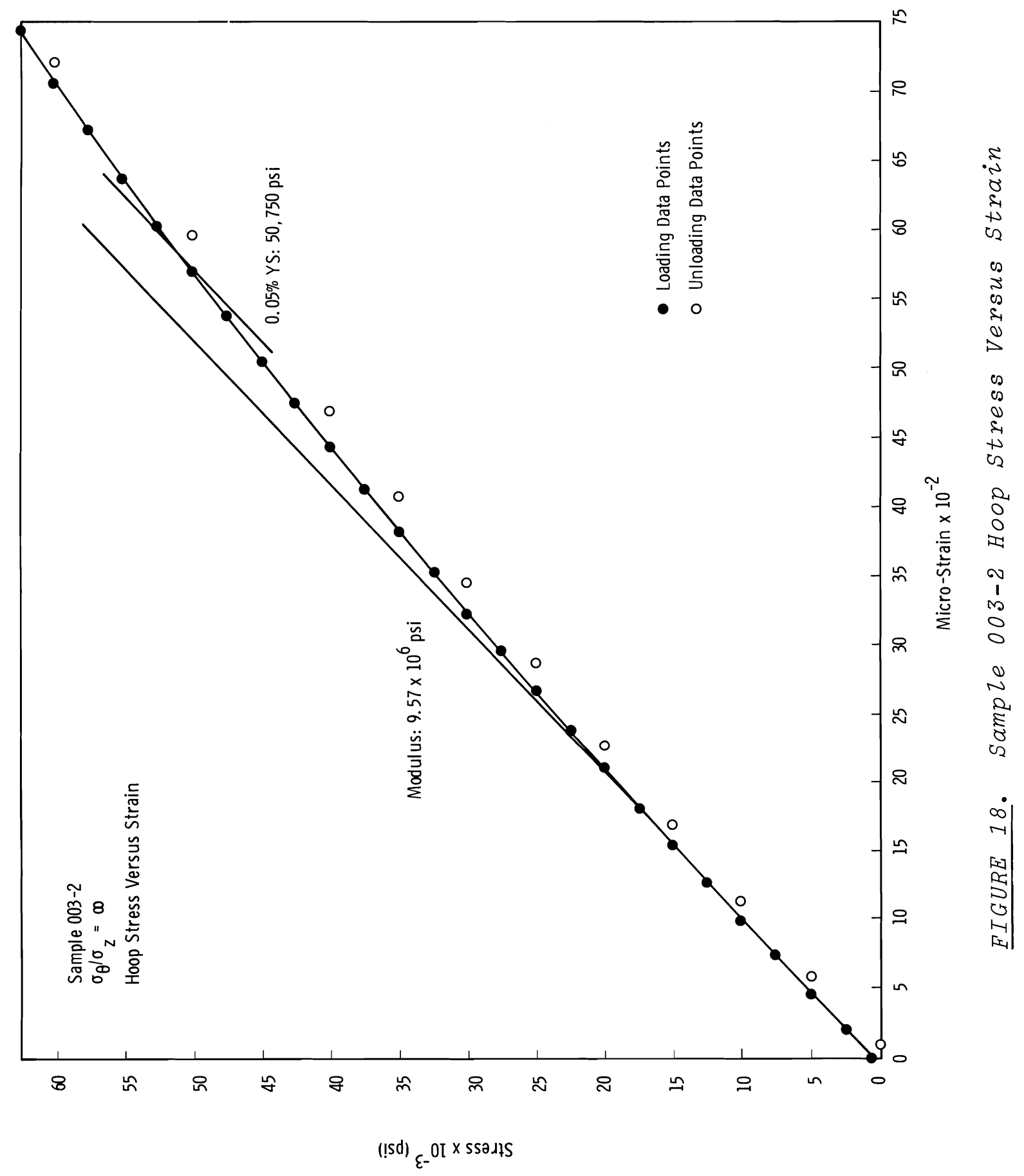


BNWL - 1112

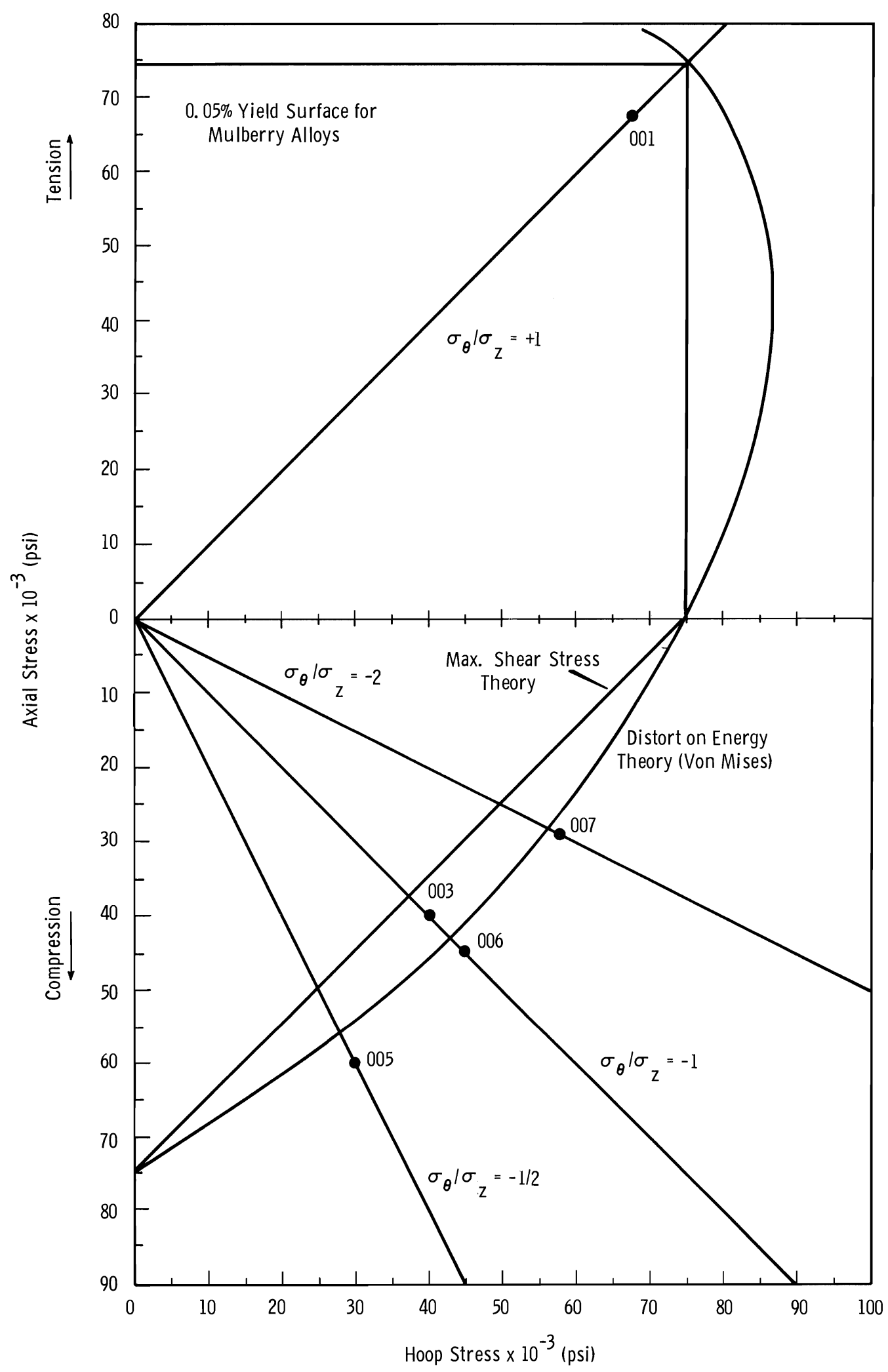

FIGURE 19. $0.05 \%$ yiezd Surface for Mulberry AZzoys 
BNWL -1112

APPENDIX

MEMORANDUM FROM UCLRL NONDESTRUCTIVE TEST ENGINEERING REPORT TO H. WEISS 
BNWL -1112

APPENDIX

MEMORANDUM FROM UCLRL NONDESTRUCTIVE TEST ENGINEERING REPORT TO H. WEISS (REFERENCE NO. 20791 - DATED JULY 30, 1968)

U1trasonic Irspection

Item 001: No defects.

Item 002: Two longitudinal cracklike defects $180^{\circ}$ apart, approximately $1-1 / 2$ and $2-1 / 2$ in. 1ong. One circumferential defect approximately $1 / 4$ in. long.

Item 003: No defects.

Item 004: One 1ongitudinal cracklike defect, approximately 2 in. long.

Item 005: No defects.

Item 006: Three longitudinal cracklike defects, each approximately $1 / 4$ in. long, located near fillets.

Item 007: No defects.

Fluorescent Pentrant Inspection

Item 001: Inner Surface: No defect indications were noted. Outer Surface: Porosity-like indications five mils to $20 \mathrm{mils}$ in diameter were detected randomly distributed throughout each of the weld areas. No other defect indications were detected.

Item 002: Inner Surface: Seven longitudinal cracklike indications, approximately $1 / 4$ in. long, were detected at $180^{\circ}$ in the cylindrical section. The indications are end to end and form a line extending to a total length of 1-1/2 in. One $1 / 4$ in. long transverse cracklike indication was detected at $270^{\circ}$ and is located near the center of the cylindrical section. 
Inner and Outer Surface: Four 1/2-in. 1ong to 1-in. long longitudinal cracklike indications were detected in the cylindrical section at zero degree. The indications are end to end and form a line extending to a total length of $2-1 / 2$ in. Penetrant was applied to the inner surface only for the purpose of a leakthrough test. The detection of penetrant leaking through these defects to the outer surface indicates that the defects extend completely through the wall thickness. Porosity-like indications five mils to $40 \mathrm{mils}$ in diameter are randomly distributed throughout each weld area.

Item 003: Inner Surface: Porosity-like indications five mils to $40 \mathrm{mils}$ in diameter are randomly distributed throughout each weld area.

Outer Surface: Multiple porosity-like indications five mils to $40 \mathrm{mils}$ in diameter were detected throughout each weld area.

Item 004: Inner Surface: Porosity-like indications five mils to $40 \mathrm{mils}$ in diameter are randomly distributed throughout each weld area.

Outer Surface: One 40-mil long longitudinal surface tear indication was detected approximately $90^{\circ}$ at the weld area. One $1 / 2$-in. long cracklike indication was detected at approximately $315^{\circ}$. The indication is somewhat longitudinal and extends through the fillet and two threads. Porosity-like indications five mils to $40 \mathrm{mils}$ in diameter are randomly distributed throughout each weld area.

One $1-5 / 8$ in. 1ong cracklike indication was detected in the cylindrical section at $270^{\circ}$. Penetrant was 
BNWL -1112

applied to the inner surface only for the purpose of a leak-through test. The detection of penetrant leaking through this defect to the outer surface indicates that the defect extends through the wall thickness.

Item 005: Outer Surface: Longitudinal surface tear indications, 1/4-in. long and 1/8-in. long, were detected extending from the fillet onto the cylindrical section at one end of the specimen.

Outer and Inner Surface: Porosity-like indications five mils to $40 \mathrm{mils}$ in diameter were detected throughout both weld areas.

Item 006: Inner Surface: A 1/4-in. 1ong somewhat longitudinal cracklike indication was detected at $90^{\circ}$ at one end of the cylindrical section. A 3/8-in. long longitudinal cracklike indication was detected at the other end at $90^{\circ}$. One $3 / 16$ in. longitudinal cracklike indication was detected in the cylindrical section at $210^{\circ}$.

Inner and Outer Surface: A minor amount of porositylike indications five mils to $40 \mathrm{mils}$ in diameter is randomly distributed throughout both weld areas.

Item 007: Outer Surface: One 40-mil long longitudinal surface tear indication was detected in the fillet area at approximately zero degree.

Inner and Outer Surface: Multiple porosity-like indications five mils to $60 \mathrm{mils}$ in diameter were detected throughout both weld areas. 
Radiographic Inspection

With the exception of one end of Part No. 4 and both ends of Part No. 6, all circumferential welds contain unconnected aligned porosity uniformly distributed, with about 40 pores per linear inch and an average size of 0.015 to 0.020 in. in diameter.

The zero degree view of Part No. 2 shows four aligned cracklike indications 0.005 in. wide and a total length of 2-3/4 in. running parallel to the axis of the part.

The $90^{\circ}$ view of Part No. 4 shows one cracklike indication parallel to the axis 0.005 in. wide $x 1-3 / 4$ in. 1ong. 


\section{DISTRIBUTION}

No. of

Copies

OFFSITE
AEC Albuquerque Operations Office

D. Johnstone

V. C. Vespe (Weapons Dev. Div.)

AEC Chicago Patent Group

G. H. Lee

AEC Division of Technical Information Extension

AEC Library, Washington

Lt. Col. Zach Hagedorn, Div. Military Application

Lawrence Radiation Laboratory, Livermore (AEC)

F. S. Eby

E. A. Green

C. R. Henry

J. O. Jepson

W. M. Miller/D. E. Loewe

H. N. Per 1

T. Perlman

W. J. Ramsey

J. L . Robbins

H. Weiss/S. Root

Los Alamos Scientific Laboratory (AEC)

R. D. Baker

W. J. Maraman

F. W. Schonfeld

Sandia Corporation, Albuquerque, (AEC)

Attn: J. Ledman

Sandia Corporation, Livermore (AEC)

D. Adolphson

M. Mote

Union Carbide Corp., (ORGDP) (AEC)

J. L. Cadden 
No. of

Copies

ONSITE - HANFORD

1

AEC Chicago Patent Group

R. K. Sharp (Richland)

2

AEC RDT Site Representative

P. G. Holsted

2

AEC Richland Operations Office

J. L. Rhodes

C. L. Robinson

Batte1le Memorial Institute

45 Batte11e-Northwest

V. C. Asmund

R. A. Busch

S. D. Dahlgren

D. R. de Halas

G. M. Dalen

H. R. Gardner

G. P. Hanneman

D. D. Hays (26)

R. R. King

E. D. McClanahan

R. D. Ne1son

R. W. Stewart

O. J. Wick

Technical Information (5)

Technical Publications (2) 